\title{
ANTIMICROBIAL EFFICACY OF CURCUMA ZEDOARIA EXTRACT AS ASSESSED BY LINEAR REGRESSION COMPARED WITH COMMERCIAL MOUTHRINSES
}

\author{
Adriana Bugno ${ }^{1 *}$; Maria Aparecida Nicoletti²; Adriana A. B. Almodóvar'; Tatiana C. Pereira $^{1}$; \\ Mariângela T. Auricchio ${ }^{1}$ \\ ${ }^{1}$ Instituto Adolfo Lutz, São Paulo, SP, Brasil; ${ }^{2}$ Faculdade de Ciências Farmacêuticas da Universidade de São Paulo, \\ Departamento de Farmácia, Farmácia Universitária, São Paulo, SP, Brasil
}

Submitted: July 31, 2006; Returned to authors for corrections: February 26, 2006; Approved: July 18, 2007.

\begin{abstract}
The antimicrobial activity of Curcuma zedoaria (Christm) Roscoe extract against some oral microorganisms was compared with the antimicrobial activity of five commercial mouthrinses in order to evaluate the potential of the plant extract to be incorporated into formulas for improving or creating antiseptic activity. The in vitro antimicrobial efficacy of plant extracts and commercial products were evaluated against Streptococcus mutans, Enterococcus faecalis, Staphylococcus aureus and Candida albicans using a linear regression method to evaluate the microbial reduction obtained in function of the exposure time, considering as effectiveness a $99.999 \%$ reduction in count of standardized microbial populations within 60 seconds. The results showed that the antimicrobial efficacy of Curcuma zedoaria (Christm) Roscoe extract was similar to that of commercial products, and its incorporation into a mouthrinse could be an alternative for improving the antimicrobial efficacy of the oral product.
\end{abstract}

Key words: Curcuma zedoaria, mouthrinse, antimicrobial activity, logarithmic reduction.

\section{INTRODUCTION}

Besides being vehicles for the delivery of active compounds in the treatment of specific problems, mouthrinses have been used in the chemical control of dental plaque biofilm to complement mechanical procedures $(1,4,10,16,24,26)$. In general, their basic composition is not complex - a vehicle (water, alcohol or glycerin), flavoring agents, surfactant agents and colorants; the differential characteristic of these products is the incorporation of antimicrobial substances, associated or not with fluoride compounds $(1,4)$.

For a long time, plants have been an important source of natural products for human health. The antimicrobial properties of plants have been investigated by a number of studies worldwide and many of them have been used as therapeutic alternatives because of their antimicrobial properties. These properties are due to compounds synthesized as secondary metabolites of the plants, such as phenolic compounds, which are part of the essential oils, as well as tannins.

The use of plant extracts and phytochemicals with known antimicrobial properties may have great significance in therapeutic treatments, and may be added to oral formulas or toothpastes in order to create or improve the antimicrobial efficacy of these products. The most used antiseptic mouthrinse is a hydro-alcoholic solution of thymol, menthol, eucalyptol and methyl salicylate. Although essential oils are frequently used as flavoring agents, they may also contribute to the antimicrobial properties of the oral products, mainly against gram-positive bacteria and yeasts, depending on the type and concentration of the oil $(1,9,10,12,15)$.

Curcuma zedoaria (Christm) Roscoe has a great variety of components such as essential oils, oil-resin, therpenic compounds and other constituents, with a wide spectrum of biological properties. Because of the presence of cineol,

*Corresponding Author. Mailing address: Instituto Adolfo Lutz. Av. Dr. Arnaldo, 355 - 01246-902 São Paulo, SP. Tel.: (11) $3068-2963$ ou (11) 30682926. E-mail: adrbugno@ial.sp.gov.br 
camphene, alpha-pinene, camphor and other compounds this plant has been used in folk medicine, against digestive and gall bladder disorders, cough, hepatic disorders and halitosis, besides presenting anti-inflammatory and antimicrobial activities (17).

Antimicrobial activity of mouthrinses may be evaluated by in vivo or in vitro methods, which are generally based on those successfully developed for applications in medicine. They include susceptibility tests, such as agar diffusion procedures, minimum inhibitory concentration (MIC) and the minimum lethal concentration (MLC) determinations, as well as time-kill testing $(5,9,10,12,16)$. The agar diffusion method may be used as a qualitative parameter of antimicrobial activity. As diffusion depends on physical-chemical properties of the product, the diameter of the inhibition zones may not be used for comparison among different formulas, and the absence of the inhibition zone may not be indicative of absence of activity. Minimum inhibitory concentration determination may be used in the quantitative evaluation of different formulas. However, this assay cannot provide information about the behavior of the product during its use.

In addition to the characterization of the activity spectrum of the product, the rate of kill must also be characterized. The test is done over time and the number of survivors is determined by direct enumeration. The kill curve generated should show microbial reduction in the time frame of use of the product. The analytical procedures that enable the evaluation of kinetic microbial death are based on those used in the preservative efficacy testing. Orth and Sutton et al. $(18,25)$ proposed the use of the linear regression method to evaluate the preservative efficacy of cosmetics, with calculation of D-value, which is the time required for decreasing the number of viable microorganisms in one logarithmic unit. This value is used as a predictor for responses beyond the data to estimate the time required for reaching a level of established activity. AOAC protocols for the sanitizing action of disinfectants ( 3 ) and the AFNOR method for the antimicrobial activity of disinfectants and antiseptics $(2,7)$ are based on the products ability to reduce microbial populations. For these protocols, the products must meet the standard effectiveness: $99.999 \%$ reduction in the counts of organisms within 30 seconds (AOAC method) or within the time of contact recommended by the manufacturer (AFNOR).

The objective of the present study was to compare the in vitro antimicrobial efficacy of Curcuma zedoaria fluid extract and commercial mouthrinses on microorganisms frequently related to oral problems $(4,5,21)$ - Streptococcus mutans (ATCC 25175), Enterococcus faecalis (ATCC 19433), Staphylococcus aureus (ATCC 6538) and Candida albicans (ATCC 10231) using the linear regression method proposed by Orth (18), evaluating the microbial reduction as a function of the exposure time, considering as effectiveness a $99.999 \%$ reduction in count of standardized microbial populations within 60 seconds.

\section{MATERIALAND METHODS}

\section{Plant extract}

Curcuma zedoaria (Christm) Roscoe used in the study was identified in the Instituto de Botânica (São Paulo/SP). The reference material kept in this herbarium is registred under number 338498. The characterization of pulverized rhizomes was: $7 \%,>0.420 \mathrm{~mm} ; 7 \%$, from 0.250 to $0.420 \mathrm{~mm} ; 24 \%$, from 0.177 to $0.250 \mathrm{~mm} ; 37 \%$ from 0.149 to $0.177 \mathrm{~mm}$ and $25 \%,<0.149 \mathrm{~mm}$.

Fluid extract was obtained by fraction percolation, using alcohol $70^{\circ}\left(\right.$ at $15^{\circ} \mathrm{C}$ ) as the extraction liquid. The antimicrobial activity of the extract was evaluated at concentration $1,000 \mathrm{mg} /$ $\mathrm{mL}$ (CZ nd), $500 \mathrm{mg} / \mathrm{mL}$ (CZ 1:2), $250 \mathrm{mg} / \mathrm{mL}$ (CZ 1:4) and 100 $\mathrm{mg} / \mathrm{mL}(\mathrm{CZ} \mathrm{1:10)}$.

\section{Antiseptic mouthrinses}

Five commercial products, available in drugstores of São Paulo/SP, Brazil, were used in the study. They were identified according to the active compound in the product:

CP cetylpyridinium chloride $(0.5 \mathrm{mg} / \mathrm{mL})$;

CP+EO cetylpyridinium chloride $(0.5 \mathrm{mg} / \mathrm{mL})$ associated with chamomile and myrrh tinctures and oils of salvia, melaleuca and eucalyptus;

EO thymol $(0.6 \mathrm{mg} / \mathrm{mL})$, eucalyptol $(0.92 \mathrm{mg} / \mathrm{mL})$, menthol $(0.42 \mathrm{mg} / \mathrm{mL})$ and methyl salicylate $(0.6 \mathrm{mg} / \mathrm{mL})$;

TCS triclosan $(0.3 \mathrm{mg} / \mathrm{mL})$ associated with a copolymer CHX chlorhexidine gluconate $(1.2 \mathrm{mg} / \mathrm{mL})$.

All commercial products were evaluated for antimicrobial activity without dilution, as indicated by the manufacturer.

\section{Preparation of culture suspension}

Stock cultures of Streptococcus mutans ATCC 25175, Enterococcus faecalis ATCC 19433, Staphylococcus aureus ATCC 6538 and Candida albicans ATCC 10231 were obtained from the culture collection of Institute Adolfo Lutz, São Paulo/SP, Brazil. From these, three consecutive daily transfers were made in Soy Casein Digest Broth (DIFCO ${ }^{\circledR}$ ) and incubated at $36 \pm 1^{\circ} \mathrm{C}$ for 24 hours. Streptococcus mutans and Enterococcus faecalis were incubated in microaerophillic environment $\left(10 \% \mathrm{CO}_{2}\right)$. The number of viable microorganisms in the third subculture was determined by the pour-plate method (8), using the same incubation conditions described above. The culture suspension, kept under refrigeration, was adjusted to $7.5 \times 10^{7}$ and $1.2 \times 10^{8}$ $\mathrm{CFU} / \mathrm{mL}$ by dilution with sterile saline solution $(2,3,7,25)$.

\section{Evaluation of antimicrobial activity Operating technique}

Nine $\mathrm{mL}$ of the product were transferred into a wide-mouth tube and placed in a water bath at $22 \pm 2^{\circ} \mathrm{C}$ for approximately 20 minutes. A culture suspension containing $\sim 10^{8} \mathrm{CFU} / \mathrm{mL}$ was prepared and $10 \mathrm{~mL}$ was added midway between the center and 
the edge of the surface with the tip of the pipette slightly immersed in the test solution. Thirty, 60 and 90 seconds after addition of the suspension, a $1.0 \mathrm{~mL}$ aliquot of this mixture was transferred to $9.0 \mathrm{~mL}$ of Letheen Broth (DIFCO ${ }^{\circledR}$ ), used to neutralize the residual antimicrobial activity of the product. The number of viable microorganisms in the broth was determined by pour-plate method (8), in Soy Casein Digest Agar (DIFCO ${ }^{\circledR}$ ), and the plates were incubated for 48 hours under the same incubation conditions used in the preparation of the culture suspension.

To determine the initial number of viable microorganisms a control test was run using sterile saline solution instead of the product.

\section{Evaluation of the capacity to neutralize the residual antimicrobial activity}

To confirm the neutralizing capacity of Letheen Broth 1.0 $\mathrm{mL}$ of the product was added to three tubes containing $9.0 \mathrm{~mL}$ of Letheen Broth and $0.4 \mathrm{~mL}$ of a culture suspension, adjusted to $1,000 \mathrm{CFU} / \mathrm{mL}$, was added to each tube. The number of viable microorganisms was determined by pour-plate method (8), in Soy Casein Digest Agar (DIFCO ${ }^{\circledR}$ ), and the plates were incubated for 48 hours under the same incubation conditions used in the preparation of the culture suspension. The microorganisms were counted and microbial recovery rate was calculated.

\section{RESULTS AND DISCUSSION}

Accurate determination of the rate of cell survival depends upon neutralization of the antimicrobial agent at a specific time point and, according to the United States Pharmacopeia (27), the absence of antimicrobial activity is indicated by microbial recovery rates over $70 \%$. Table 1 indicates that the Letheen Broth neutralized the residual antimicrobial activity of the plant extract and the commercial products used in the study.

All determinations were made using normalized data points. The number of survivors was expressed as the $\log 10$ of the fraction remaining of the original inoculum, normalized to approximately $10^{7} \mathrm{CFU} / \mathrm{mL}$. The time course incorporated three points. Three replicates were done in three separate days. A kill curve ( $\log _{10} \mathrm{CFU} / \mathrm{mL}$ vs. time) was drawn for each product, and linear regression analysis for each set of data was made.

Figure 1 shows the kill curves obtained for Curcuma zedoaria extracts, for the four tested microorganisms. Considering as effective the product that reduces $99.999 \%$ of microbial population within one minute, only samples $\mathrm{CZ}$ nd and $\mathrm{CZ} \mathrm{1:2} \mathrm{presented} \mathrm{satisfactory} \mathrm{results.}$

Based on the kill curves, Table 2 shows the calculated equations and time for $99.999 \%$ reductions $\left(\mathrm{T}_{99.999 \%}\right.$ ) for $\mathrm{CZ}$ nd and CZ 1:2 extracts and for each commercial product analyzed.

Considering as effectiveness a $99.999 \%$ reduction of microbial population within 60 seconds of contact, Table 2 shows that $\mathrm{CZ}$ nd was able to reduced the counts of all microorganisms in more than five logarithmic cycles. The best results were obtained for Staphylococcus aureus and Candida albicans, as shown in a previous study (17), where a lower minimum inhibitory (CIM) values for these microorganisms was reported. Among the commercial products analyzed, EO presented the greatest antimicrobial activity for all microorganisms, whereas TCS presented the second best antibacterial activity, and sample $\mathrm{CHX}$, the second best antifungal activity. In relation to the products based on cetylpyridinium chloride, sample $\mathrm{CP}+\mathrm{EO}$ presented better antimicrobial activity than sample $\mathrm{CP}$, probably due to the association with essential oils.

Although the minimum inhibitory concentration (MIC) has been used for evaluating the antimicrobial activity, McBain $e t$ al. (11) and McDonnell and Russel (12) observed that triclosan and chlorhexidine presented high antimicrobial potential against oral bacteria and, MIC obtained for triclosan was lower than the one obtained for chlorexidine. Pan et al. (19), Riep et al. (22), and Pitten and Kramer (20) evaluated the rate of microbial death after contact with antiseptic mouthrinses and observed that products containing essential oils were more effective. BouChacra et al. (6), who evaluated the antimicrobial activity of dental gel formulas on cariogenic bacteria using the linear

Table 1. Recovery rate (R) of Streptococcus mutans, Staphylococcus aureus, Enterococcus faecalis and Candida albicans obtained in the evaluation of Letheen Broth $\left(\mathrm{DIFCO}^{\circledR}\right)$ as a neutralizer of residual activity.

\begin{tabular}{ccccccccc}
\hline \multirow{2}{*}{ Product } & \multicolumn{2}{c}{ Streptococcus mutans } & \multicolumn{2}{c}{ Staphylococcus aureus } & \multicolumn{2}{c}{ Enterococcus faecalis } & \multicolumn{2}{c}{ Candida albicans } \\
\cline { 2 - 8 } & CFU & $\mathbf{R}(\%)$ & CFU & $\mathbf{R}(\%)$ & CFU & $\mathbf{R}(\%)$ & CFU & $\mathbf{R}(\%)$ \\
\hline Control & $46 / 42 / 50$ & & $48 / 50 / 48$ & & $42 / 48 / 48$ & & $46 / 51 / 48$ & \\
CZnd & $43 / 40 / 45$ & 92.75 & $44 / 46 / 44$ & 91.78 & $42 / 45 / 44$ & 95.65 & $43 / 45 / 46$ & 92.41 \\
CP & $42 / 42 / 48$ & 95.65 & $46 / 49 / 47$ & 97.12 & $40 / 48 / 46$ & 97.17 & $44 / 46 / 46$ & 93.79 \\
CP+EO & $43 / 40 / 48$ & 95.00 & $46 / 46 / 48$ & 95.89 & $41 / 46 / 46$ & 96.30 & $42 / 46 / 46$ & 92.55 \\
EO & $43 / 40 / 45$ & 92.83 & $48 / 48 / 44$ & 95.89 & $40 / 46 / 47$ & 96.30 & $44 / 48 / 46$ & 95.24 \\
TCS & $44 / 40 / 46$ & 94.13 & $45 / 48 / 46$ & 95.07 & $40 / 45 / 46$ & 95.00 & $42 / 48 / 44$ & 92.55 \\
CHX & $42 / 39 / 46$ & 91.96 & $44 / 46 / 42$ & 90.35 & $42 / 42 / 46$ & 94.13 & $42 / 44 / 46$ & 91.10 \\
\hline
\end{tabular}


Table 2. Equation, $\mathrm{R}^{2}$ and time for a $5 \log _{10}$ reduction of Streptococcus mutans (A), Staphylococcus aureus (B), Enterococcus faecalis (C) and Candida albicans (D).

(A)

\begin{tabular}{lccc}
\hline Product & Equation & $\mathrm{R}^{2}$ & $\mathrm{~T}_{99,999 \%}(\mathrm{sec})$ \\
\hline CZnd & $\mathrm{y}=-0.085 \mathrm{x}+6.724$ & 0.972 & 59.10 \\
CZ 1:2 & $\mathrm{y}=-0.064 \mathrm{x}+6.57$ & 0.969 & 78.74 \\
CP & $\mathrm{y}=-0.080 \mathrm{x}+6.543$ & 0.912 & 62.74 \\
CP+EO & $\mathrm{y}=-0.085 \mathrm{x}+6.181$ & 0.777 & 58.62 \\
EO & $\mathrm{y}=-0.089 \mathrm{x}+6.786$ & 0.985 & 56.37 \\
TCS & $\mathrm{y}=-0.085 \mathrm{x}+6.131$ & 0.755 & 58.62 \\
CHX & $\mathrm{y}=-0.060 \mathrm{x}+6.565$ & 0.943 & 82.78 \\
\hline
\end{tabular}

(C)

\begin{tabular}{lccc}
\hline Product & Equation & $\mathrm{R}^{2}$ & $\mathrm{~T}_{99,999 \%}(\mathrm{sec})$ \\
\hline CZnd & $\mathrm{y}=-0.089 \mathrm{x}+6.753$ & 0.980 & 56.37 \\
CZ 1:2 & $\mathrm{y}=-0.079 \mathrm{x}+6.610$ & 0.934 & 63.69 \\
CP & $\mathrm{y}=-0.075 \mathrm{x}+6.710$ & 0.986 & 66.84 \\
CP+EO & $\mathrm{y}=-0.089 \mathrm{x}+6.215$ & 0.805 & 56.24 \\
EO & $\mathrm{y}=-0.100 \mathrm{x}+6.824$ & 0.993 & 50.25 \\
TCS & $\mathrm{y}=-0.090 \mathrm{x}+6.079$ & 0.750 & 55.87 \\
CHX & $\mathrm{y}=-0.028 \mathrm{x}+6.768$ & 0.905 & 179.21 \\
\hline
\end{tabular}

(B)

\begin{tabular}{lccc}
\hline Product & Equation & $\mathrm{R}^{2}$ & $\mathrm{~T}_{99,999 \%}(\mathrm{sec})$ \\
\hline CZnd & $\mathrm{y}=-0.091 \mathrm{x}+6.604$ & 0.948 & 54.70 \\
CZ 1:2 & $\mathrm{y}=-0.065 \mathrm{x}+6.880$ & 0.999 & 76.45 \\
CP & $\mathrm{y}=-0.040 \mathrm{x}+6.778$ & 0.980 & 124.38 \\
CP+EO & $\mathrm{y}=-0.068 \mathrm{x}+6.880$ & 0.996 & 73.96 \\
EO & $\mathrm{y}=-0.095 \mathrm{x}+6.385$ & 0.887 & 52.52 \\
TCS & $\mathrm{y}=-0.074 \mathrm{x}+6.384$ & 0.824 & 67.84 \\
CHX & $\mathrm{y}=-0.034 \mathrm{x}+6.967$ & 0.979 & 145.77 \\
\hline
\end{tabular}

(D)

\begin{tabular}{lccc}
\hline Product & Equation & $\mathrm{R}^{2}$ & $\mathrm{~T}_{99,999 \%}(\mathrm{sec})$ \\
\hline CZnd & $\mathrm{y}=-0.087 \mathrm{x}+6.659$ & 0.958 & 57.47 \\
CZ 1:2 & $\mathrm{y}=-0.067 \mathrm{x}+6.868$ & 0.6984 & 74.63 \\
CP & $\mathrm{y}=-0.061 \mathrm{x}+6.340$ & 0.911 & 82.64 \\
CP+EO & $\mathrm{y}=-0.063 \mathrm{x}+6.681$ & 0.933 & 79.37 \\
EO & $\mathrm{y}=-0.100 \mathrm{x}+6.159$ & 0.820 & 49.85 \\
TCS & $\mathrm{y}=-0.072 \mathrm{x}+6.437$ & 0.843 & 69.83 \\
CHX & $\mathrm{y}=-0.085 \mathrm{x}+6.231$ & 0.799 & 58.62 \\
\hline
\end{tabular}

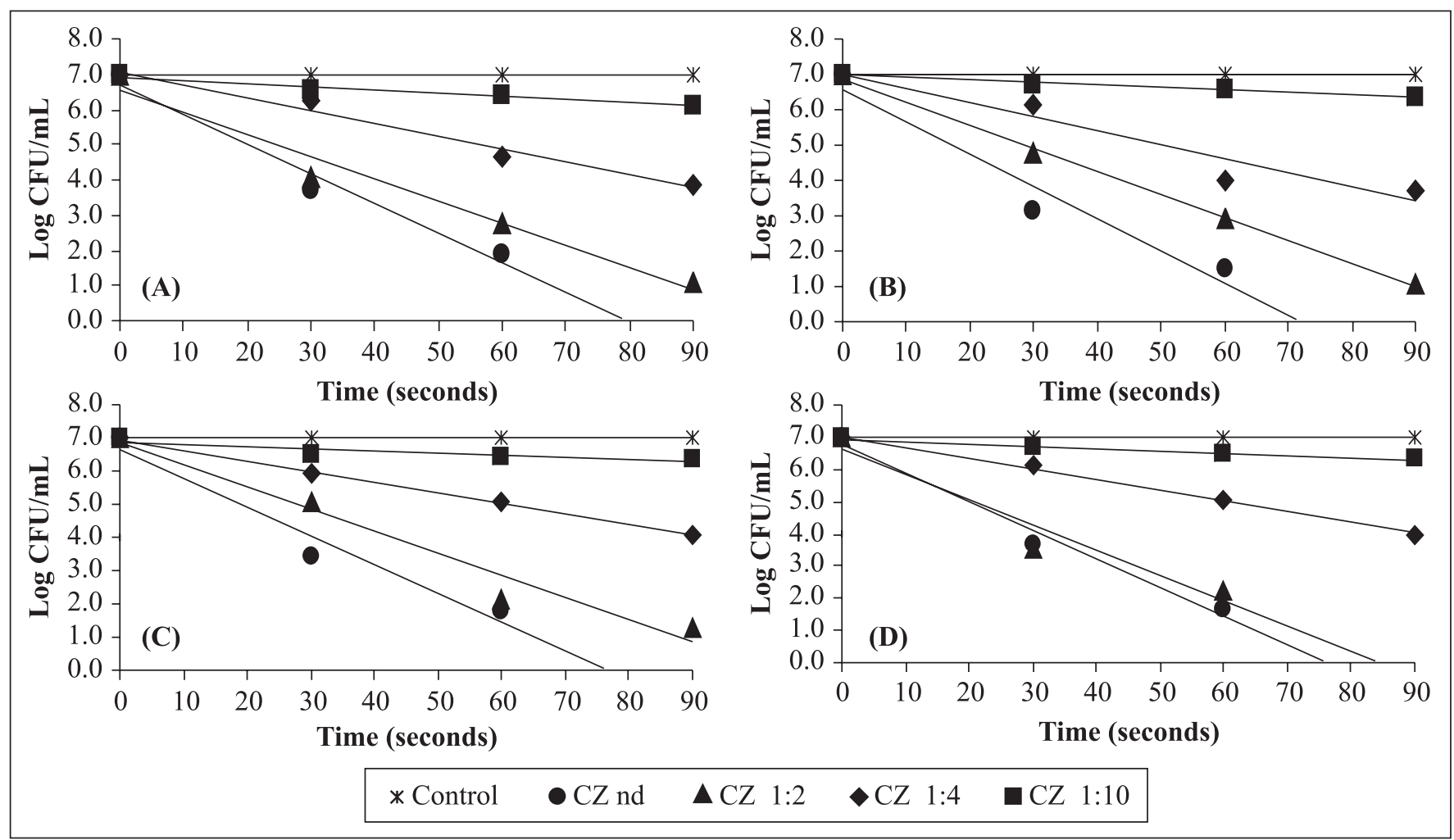

Figure 1. Linear regression modeling of data from the trials with different concentrations of Curcuma zedoaria fluid extract against Streptococcus mutans (A) Staphylococcus aureus (B), Enterococcus faecalis (C) and Candida albicans (D). 
regression method, noticed that formulas containing essential oils showed higher bactericidal activity . Meiller et al. (15), who evaluated the antifungal efficacy of three formulas containing essential oils and one containing chlorhexidine, observed that all products presented activity against yeasts in the commercially available concentration and, the formulas containing essential oils showed better results.

Results indicated that the antimicrobial activity of Curcuma zedoaria is similar to that of commercial formulas containing essential oils (EO and $\mathrm{CP}+\mathrm{EO}$ ) against all microorganisms studied. CZ nd presented the lowest activity against all microorganisms when compared with EO, but against Enterococcus faecalis and Streptococcus mutans, CZ nd also presented the lowest activity compared with $\mathrm{CP}+\mathrm{EO}$.

Some studies showed that in vitro antimicrobial activity may not correlate were with clinical activity $(5,10)$. For instance, Renton-Harper et al. (23) observed that formulas containing chlorhexidine presented greater antimicrobial activity than cetylpyridinium chloride and triclosan, as well as Monfrin and Ribeiro (14), whose experiments indicated that products containing chlorhexidine were more effective in reducing microbial populations in the saliva of volunteers, whereas products containing triclosan led to small decreases, and those containing essential oils did not reduce microbial populations.

Differences observed between in vivo e in vitro methods may be related to adsorption characteristics of the antimicrobial agents, to whether the inhibitor has a biocidal or biostatic effect on the microorganisms, to the kinetics of inhibition, to the penetration of agent into the biofilm, to the lower sensitivity to antimicrobial agents observed in biofilms and to the enviromental conditions within dental plaque biofilm $(5,10)$. In spite of eventual differences, in vitro tests using cultures in suspension enabled a preliminary evaluation of the antimicrobial activity of antiseptic mouthrinses.

In conclusion, the EO product showed remarkable antimicrobial activity, in assay conditions, on all microorganisms studied, whereas TCS presented the second best antibacterial activity and $\mathrm{CHX}$, the second best antifungal activity. Curcuma zedoaria (Christm) Roscoe fluid extract demonstrated a dosedependent antimicrobial efficacy similar to that of commercial products, showing that its incorporation into a mouthrinse is an alternative for improving the antimicrobial efficacy of the oral product.

\section{RESUMO}

\section{Eficácia antimicrobiana do extrato de Curcuma zedoaria avaliada por regressão linear comparada com anti-sépticos bucais comerciais}

A atividade antimicrobiana do extrato de Curcuma zedoaria (Christm) Roscoe contra algumas bactérias da microbiota bucal foi comparada com a atividade antimicrobiana de cinco antisépticos comerciais, a fim de avaliar o potencial do extrato vegetal de ser incorporado em formulações com a finalidade de melhorar ou conferir atividade anti-séptica. A eficácia antimicrobiana in vitro do extrato vegetal e produtos comerciais foi avaliada frente a Streptococcus mutans, Enterococcus faecalis, Staphylococcus aureus e Candida albicans, utilizando o método de regressão linear para avaliar a redução microbiana obtida em função do tempo de exposição, considerando como eficácia a redução de $99,999 \%$ na contagem de população microbiana padronizada em 60 segundos. Os resultados demonstraram que a eficácia antimicrobiana do extrato de Curcuma zedoaria (Christm) Roscoe foi similar a de produtos comerciais e que sua incorporação em anti-sépticos bucais pode ser uma alternativa para aumentar a eficácia antimicrobiana de produtos para uso oral.

Palavras-chave: Curcuma zedoaria, anti-séptico bucal, atividade antimicrobiana, redução logarítmica.

\section{REFERENCES}

1. Adams, D.; Addy, M. (1994). Mouthrinses. Adv. Dent. Res., 8(2), 291-301.

2. [AFNOR] Association Française de Normalisation. (1997). Norme Européenne, Norme Française - NF EN 1040 - Antiseptiques et disinfectants chimiques; Activité bactericide de base - Méthode d'éssai et prescripitions (phase 1). Association Française de Normalisation, Paris.

3. [AOAC] Association of Official Analytical Chemists. (2000). AOAC Official Method 960.09 - Germicidal and detergent sanitizing action of disinfectants. Official Methods of Analysis of AOAC International. AOAC International, Gaithersburg.

4. Bonadeo, I. (1988). Cosmética. Ciência y Tecnologia. Ed Ciência, Madri.

5. Botelho, M.G. (2000). Fractional innibitory concentration index of combinations of antibacterial agents against cariogenic organisms. J. Dentistry, 28, 565-570.

6. Bou-Chacra, N.A.; Gobi, S.S.; Ohara, M.T.; Pinto, T.J.A. (2005). Antimicrobial activity of four different dental gel formulas on cariogenic bacteria evaluated using the linear regression method. Braz. J. Pharm. Sci., 41, 323-331.

7. Cremieux, A.; Fleurette, J. (1991). Methods of testing disinfectants. In: Block S.S. Desinfection, Sterilization and Preservation. Lea \& Febiger, Philadelphia, p.1009-1027.

8. Farmacopéia Brasileira. (1988). Atheneu Ed, São Paulo, p.v.5.1.6.1-v.5.1.6.-5.

9. Hobson, D.W.; Bolsen, K. (2001). Methods of testing oral and topical antiseptics and antimicrobial. In: Block S.S. Desinfection, Sterilization and Preservation. Lippincott Williams \& Wilkins, Philadelphia, p.1329-1359.

10. Marsh, P.D. (1992). Microbiological aspects of the chemical control of plaque and gingivitis. J. Dent. Res., 71(7), 1431-1438.

11. McBain, A.J.; Bartolo, R.G.; Catrenich, C.E.; Charbonneau, D.; Ledder, R.G.; Gilbert, P. (2003). Effects of triclosan-containing rinse on the dynamics and antimicrobial susceptibility of in vitro plaque ecosystems. Antimicrob. Agents. Chemother., 47(11), 3531-3538.

12. McDonnell, G.; Russel, D. (1999). Antiseptics and disinfectants. Activity, action and resistance. Clin. Microbiol. Rev., 12(1), 147-179. 
13. Meiller, T.F.; Kelley, J.I.; Jabra-Rizk, M.A.; DePaola, L.G.; Abdullahel Baqui, A.A.M.; Falkler, W.A. (2001). In vitro studies of the efficacy of antimicrobials against fungi. Oral Surg. Oral Med. Oral Pathol. Oral Radiol. Endod., 91, 663-670.

14. Monfrim, R.C.P.; Ribeiro, M.C. (2000). Avaliação in vitro de antisépticos orais sobre a microbiota da saliva. Rev. APCD, 54(5), 400-407.

15. Nascimento, G.G.F.; Locatelli, J.; Freitas, P.C.; Silva, G.L. (2000) Antibacterial activity of plant extracts and phytochemicals on antibiotic-resistant bacteria. Braz. J. Microbiol., 31, 247-256.

16. Newman, M.G.; Hulem, C.; Colgate, J.; Anselmo, C. (1979). Antibacterial susceptibility of plaque bacteria. J. Dent. Res., 58(7), 1722-1732.

17. Nicoletti, M.A.; Bugno, A.; Orsine, E.M.A.; Zenebon, O. (2003). Estudo da atividade antimicrobiana do extrato fluido da Curcuma zedoaria (Christm) Roscoe - Determinação da concentração mínima inibitória. Rev. Bras. Farm., 84(2): 39-41.

18. Orth, D.S. (1979). Linear regression method for rapid determination of cosmetic preservative efficacy. J. Soc. Cosmet. Chem., 30, 321332.

19. Pan, P.H.; Finnegan, M.B.; Sturdivant, L.; Barnett, M.L. (1999). Comparative antimicrobial activity of an essential oil and an amine fluoride-stannous fluoride mouthrinse in vitro. J. Clin. Periodontol., 26(7), 474-476.
20. Pitten, F.A.; Kramer, A. (1999). Antimicrobial efficacy of antiseptic mouthrinse solutions. Eur. J. Clin. Pharmacol., 55(2), 95-100.

21. Prista, L.N.; Bahia, M.F.G.; Vilar, E. (1995). Dermofarmácia e Cosmética. Associação Nacional de Farmácias, Porto.

22. Riep, B.G.; Bernimoulin, J.P.; Barnett, M.L. (1999). Comparative antiplaque effectiveness of an essential oil and an amine fluoridstannous fluoride mouthrinse. J. Clin. Periodontol., 26(3), 164-8.

23. Renton-Harper, P.; Addy, M.; Moran, J.; Doherty, F.M.; Newcombe, R.G. (1996). A comparison of chlorhexidine, cetylpyridinium chloride, triclosan, and $\mathrm{C} 31 \mathrm{G}$ mouthrinse products for plaque inhibition. $J$. Periodontol., 67(5), 486-489.

24. Steinberg, D.; Hirschfeld, Z.; Tayeb, I.; Ben-Yosef, S.; David, A.; Friedman, M. (1999). The effect of parabens in a mouthwash and incorporated into a sustained release varnish on salivary bacteria. $J$. Dentistry, 27, 101-106

25. Sutton, S.V.W, Porter, D. (2002). Development of the antimicrobial effectiveness test as USP chapter <51>. PDA J. Pharm. Sci. Technol., 56(6), 300-311.

26. Tawaeechaisupapong, S.; Wongkham, S.; Chareonsuk, S.; Suparee, S.; Pennapar, S.; Somsamorn, C. (2000). Selective activity of Streblus asper on Mutans streptococci. J. Ethnopharmacol., 70, 73-79.

27. United States Pharmacopeia. (2005). United States Pharmacopeial Convention, Rockville, p.1809-1818. 